\title{
Penggunaan Analytical Hierarchy Process (AHP) Untuk Pemilihan Supplier Bahan Baku
}

\author{
Addien Agustina Khairun Nisa', Subiyanto*, Sri Sukamta \\ a,b,c Pendidikan Teknik Informatika dan Komputer, Teknik Elektro, \\ Fakultas Teknik, Universitas Negeri Semarang
}

Naskah Diterima : 15 Maret 2019; Diterima Publikasi : 23 Juni 2019

DOI : 10.21456/vol9iss1pp86-93

\begin{abstract}
The purpose of this paper is to present a decision support system supplier selection of food industry raw materials especially cake and bakery, by using new technology that is famous for its robustness that is Analytical Hierarchy Process (AHP). The importance of this research is to find a new varian of the AHP application, therefore increase scientific literature related the method especially for cake and bakery industrial. Furthemore, to provide a reference of selecting raw materials supplier methods in the industry. The model starts by identifying the main criteria (quality, price, delivery, and service) using the main criteria ranking based on the opinions of experts using AHP. The second stage is identifying the sub criteria (materials supplied halal and equipped with halal certificates, sample tests and physical observations, price of goods, maximum and continuous capacity and supply capacity, discount price levels and certain purchases, the existence of supplier offices and cooperation and reference commitments) and their ranking based on the main criteria. The results of this study indicate that the Analytical Hierarchy Process (AHP) method can produce a decision support system that the right results according to field data at Virgin Cake and Bakery. The results of this study indicate that overall the best supplier to be chosen by the company to be use as a long-term co-worker is supplier A because overall this supplier has the highest value compared to the other three suppliers.
\end{abstract}

Keywords : Decision Support System; Supplier Selection; Analytical Hierarchy Process (AHP)

\begin{abstract}
Abstrak
Tujuan dari artikel ini adalah untuk menyajikan suatu sistem pendukung keputusan dalam pemilihan supplier bahan baku industri makanan khususnya Cake and Bakery, dengan menggunakan teknologi baru yang sangat baik kemampuannya yaitu Analytical Hierarchy Process (AHP). Pentingnya penelitian ini adalah untuk mendapatakan variasi baru penerapan AHP sehinggha menambah literatur ilmiah terkait khususnya di dunia industri makanan cake and bakery. Lebih jauh, untuk memberikan salah satu acuan metode pemilihan supplier bahan baku di industri. Model dimulai dengan mengidentifikasi kriteria utama (kualitas, harga, pengiriman, dan pelayanan) menggunakan peringkat kriteria utama berdasarkan pendapat para ahli untuk diinterpretasikan dalam AHP. Tahap kedua dalam metodologi yang diadopsi adalah identifikasi sub kriteria (bahan yang disupplai halal dan dilengkapi dengan sertifikat halal, uji sampel dan pengamatan fisik, harga barang, kemampuan dan kapasitas supplai maksimal dan kontinu, tingkat harga diskon dan pembelian dalam jumlah tertentu, keberadaan kantor supplier, dan komitmen kerjasama dan referensi) dan peringkat mereka berdasarkan kriteria utama. Sistem ini telah menghasilkan suatu sistem pemilihan supplier yang cerdas dan telah divalidasi dengan data real di Virgin Cake and Bakery. Hasil ini menunjukkan bahwa secara keseluruhan supplier terbaik yang akan dipilih oleh perusahaan untuk dijadikan sebagai rekan kerja jangka panjang adalah supplier A karena secara keseluruhan supplier ini memliki nilai paling tinggi dibandingkan dengan tiga supplier yang lain.
\end{abstract}

Kata Kunci : Sistem Pendukung Keputusan; Pemilihan Supplier; Analytical Hierarchy Process (AHP)

\section{Pendahuluan}

Supplier sebagai pihak penyedia bahan baku, sangat berperan penting dalam menentukan kualitas produk dan kelancaran proses produksi (Sulistiana dan Yuliawati, 2012). Hal ini dikarenakan bahan baku merupakan komponen utama bagia sebuah industri. Perusahaan yang bijak sudah tentu mempunyai lebih dari satu supplier untuk mengantisipasi order dalam *) Koresponden: subiyanto@mail.unnes.ac.id jumlah besar yang tidak bisa dipenuhi oleh satu supplier (Nugraha dan Wirdayanti, 2013). Pemilihan supplier yang tepat secara signifikan akan mengurangi biaya pembelian material dan meningkatkan daya saing perusahaan (Xia dan $\mathrm{Wu}$, 2007). Pemilihan supplier merupakan proses dimana perusahaan harus terlebih dahulu mengidentifikasi, kemudian menilai, dan akhirnya kontrak dengan supplier (Beil, 2010). 
Hasan (2008) menyatakan bahwa, pemilihan supplier bahan baku adalah salah satu komponen terpenting dalam manajemen rantai pasokan dimana keberhasilan jangka pendek dan jangka panjang dari suatu perusahaan akan sangat bergantung pada pemilihan supplier yang tepat. Apabila bahan baku yang disediakan oleh supplier buruk, maka akan berpengaruh terhadap kualitas produk yang dihasilkan. Apabila supplier tidak bisa menyediakan bahan baku sesuai kebutuhan perusahaan, maka dapat dipastikan bahwa jadwal produksi akan terganggu yang menyebabkan perusahaan tidak sukses dalam mencapai visinya. Salah satu faktor kesuksesan sebuah perusahaan adalah pemilihan pemasok (Gencer dan Gurpinar, 2011). Pada umumnya, permasalahan yang timbul adalah sulitnya menentukan supplier terbaik dari banyak pilihan yang ada dengan mempertimbangkan kriteria yang diinginkan terhadap calon supplier. Untuk memilih supplier yang dapat dikatakan layak dan sesuai dengan kriteria perusahaan, tentunya dibutuhkan sistem pendukung keputusan. Sistem pendukung keputusan merupakan sistem yang digunakan untuk membantu dalam penyelesaian masalah dan dukungan keputusan (Chamid,2015). Supply Chain Management adalah pengelolaan informasi barang dan jasa dari pemasok (supplier) paling awal sampai ke konsumen paling akhir dengan menggunakan pendekatan sistem yang terintegrasi untuk tujuan yang sama (Ilham, 2006). Ada banyak multi-kriteria pengambilan keputusan yang dilaksanakan dalam studi kriteria pemilihan supplier sebelumnya seperti DEA, ANP, AHP , dan TOPSIS. AHP adalah multi-kriteria pengambilan keputusan metode umum. AHP menggunakan perbandingan berpasangan dari kriteria penting sehubungan dengan tujuan. Perbandingan berpasangan ini memungkinkan bobot relatif dari krioteria sehubungan dengan tujuan utama. Jika data kuantitaif tersedia, maka perbandingan dapat dengan mudah dibentuk berdasarkan skala yang ditentukan atau rasio dan ini menyebabkan konsistensi akan sama dengan nol yang mengarah ke penilaian sempurna (Dweiri et al., 2016).

Penerapan metode Analytical Hierarchy Process (AHP) telah dilakukan oleh beberapa penelitian pengambilan keputusan seperti, web-based system dengan AHP untuk mengevaluasi pemilihan supplier (Akarte et al., 2001), pembuatan keputusan dalam memilih supplier (Mulalidharan et al., 2002), pengembangan model seleksi interaktif dengan AHP untuk pengambilan keputusan dalam memilih supplier (Chan, 2003), evaluasi dan pemilihan supplier dengan metode AHP (Chan et al., 2004; Liu et al., 2003), supplier otomotif (Fikri Dweiri, 2016). Namun AHP belum diaplikasikan untuk pemilihan supplier bahan baku industri Cake and Bakery, sehingga sejauh mana performa AHP untuk pemilihan supplier Cake and Bakery belum diketahui.
Virgin Cake and Bakery merupakan perusahaan yang bergerak dalam bidang pangan dengan produk yang mencapai ratusan jenis. Di Virgin Cake and Bakery hanya menerapkan pola decision making yang menggunakan metode sederhana untuk menyeleksi supplier, akan tetapi belum menggunakan sistem pendukung keputusan. Decision making merupakan suatu tindakan yang dilakukan oleh manajemen untuk mencapai tujuan organisasi dan pengambilan keputusan ini dapat didefinisikan sebagai pemilihan alternatif. Dimana dalam penggunaan decision making perusahaan mengalami kendala pada masa reorganisasi, saat masa reorganisasi karyawan lama membutuhkan waktu untuk mengajarkan penggunaan decision making kepada karyawan baru. Maka dari itu perlu diterapkan pemilihan supplier menggunakan sistem pendukung keputusan untuk menentukan supplier terbaik secara kontinu. Tujuan dari penelitian ini adalah untuk mendapatkan suatu sistem pendukung keputusan dalam pemilihan supplier bahan baku industri makanan khususnya Cake and Bakery, dengan menggunakan teknologi baru yang handal kemampuannya yaitu Analytical Hierarchy Process (AHP).

\section{Kerangka Teori}

\subsection{Sistem Pendukung Keputusan}

Sistem Pendukung Keputusan merupakan sistem informasi interaktif yang menyediakan informasi, pemodelan, dan pemanipulasian data. Sistem Pendukung Keputusan tidak dimaksudkan untuk mengotomatisasi pengambilan keputusan, tetapi memberikan perangkat interaktif yang memungkinakan pengambil keputusan untuk melakukan berbagai analisis menggunakan metodemetode yang tersedia (Alter, 2007).

\subsection{Pemilihan Supplier}

Pemilihan supplier merupakan salah satu hal yang penting dalam aktivitas pembelian bagi perusahaan. Pemilihan supplier merupakan masalah multi kriteria yang meliputi faktor-faktor kuantitatif dan kualitatif (Rahmayanti, 2010). Kriteria dan subkriteria pemilihan supplier dapat diidentifikasi oleh tinjauan literatur. Bobot masing-masing kriteria dan subkriteria akan ditentukan oleh pendapat ahli melalui survey ahli. Tujuan dari survey ini adalah hanya untuk menghitung faktor penentu keberhasilan yang akan membentuk dasar untuk mengidentifikasi kriteria dan subkriteria untuk merumuskan model AHP (Dweiri, 2016).

\subsection{Analytical hierarchy Process (AHP)}

Metode Analytical Hierarchy Process (AHP) dapat menyelesaikan masalah multikriteria yang kompleks menjadi suatu hirarki. Masalah yang kompleks dapat diartikan bahwa kriteria dari suatu masalah yang begitu banyak (multikriteria), struktur 
masalah yang belum jelas, ketidakpastian pendapat dari pengambilan keputusan, pengambilan keputusan lebih dari satu orang, serta ketidakakuratan data yang tersedia. Menurut saaty, hirarki didefinisikan sebagai suatu representasi dari sebuah permasalahan yang kompleks dalam suatu struktur multi level dimana level pertama adalah tujuan, yang diikuti level faktor, kriteria, sub kriteria, dan seterusnya ke bawah hingga level terakhir dari alternatif. Dengan hirarki, suatu masalah yang kompleks dapat diuraikan ke dalam kelompok-kelompoknya yang kemudian diatur menjadi suatu bentuk hirarki sehingga permasalahan akan tampak lebih terstruktur dan sistematis.

Metode ini adalah sebuah kerangka untuk mengambil keputusan dengan efektif atas persoalan dengan menyederhanakan dan mempercepat proses pengambilan keputusan dengan memecahkan persoalan tersebut kedalam bagian-bagiannya, menata bagian atau variabel ini dalam suatu susunan hirarki, memberi nilai numerik pada pertimbangan subjektif tentang pentingnya tiap variabel dan mensintesis berbagai pertimbangan ini untuk menetapkan variabel yang mana yang memiliki prioritas paling tinggi dan bertindak untuk mempengaruhi hasil pada situasi tersebut. Metode ini juga menggabungkan kekuatan dari perasaan dan logika yang bersangkutan pada berbagai persoalan, lalu mensintesis berbagai pertimbangan yang beragam menjadi hasil yang cocok dengan perkiraan secara intuitif sebagaimana yang dipresentasikan pada pertimbangan yang telah dibuat. Langkah-langkah dalam metode AHP adalah:

a. Menentukan jenis-jenis kriteria yang akan digunakan.

b. Menyusun kriteria-kriteria tersebut dalam matriks berpasangan

$a_{i j}=\frac{w_{i}}{w_{j}}, i, j=1,2,3, \ldots \ldots, n$

Dimana $n$ menyatakan jumlah kriteria yang dibandingkan, $w_{i}$ menyatakan bobot untuk kriteria ke- $i$ dan $a_{i j}$ adalah perbandingan bobot kriteria $i$ dan $j$.

c. Menormalkan setiap kolom dengan cara membagi setiap kolom dengan cara membagi setiap nilai pada kolom ke $i$ dan baris ke $j$ dengan nilai total dari setiap kolom.

$a_{i j}=\frac{a_{i j}}{\Sigma a_{i j}}$

d. Menentukan bobot priritas setiap kriteria ke $i$, dengan membagi jumlah setiap nilai $a$ dengan jumlah kriteria yang dibandingkan $(n)$. $w_{i}=\frac{\Sigma a}{n}$

e. Menentukan WSF (Weight Single Factor) dengan rumus.

$a_{i j}=\sum_{i=1}^{n} a_{i j} \times w_{i}$

f. Menentukan nilai CF (Consistency Factor) dengan rumus.

$C F=\frac{W S F}{B o b o t}$

g. Menghitung nilai $\lambda \max$ atau rata-rata $\mathrm{CF}$ dengan rumus.

$$
\lambda_{\max }=\frac{\Sigma C F}{n}
$$

h. Menghitung CI (Consistency Index) menggunakan persamaan.

$$
C I=\frac{\lambda_{\max }-n}{n-1}
$$

i. Mengukur seluruh konsistensi penilaian dengan menggunakan konsistensi rasio (CR) dengan rumus:

$$
C R=\frac{C I}{R I}
$$

j. Suatu tingkat konsistensi tertentu diperlukan dalam penentuan prioritas untuk mendapatkan nilai yang terbaik. Nilai $\mathrm{CR} \leq 0,01$ adalah nilai konsistensi. Jika tidak maka diperlukan revisi. Pada tabel 1 menunjukkan nilai Random Index (RI).

k. Penentuan nilai bobot prioritas diperoleh dari penjumlahan nilai bobot perbandingan antara kriteria dikalikan dengan nilai bobot perbandingan alternatif dengan kriteria.Bobot prioritas = $\sum$ (bobot perbandingan antar kriteria $\times$ bobot perbandingan alternatif dengan kriteria) (2.9)

\subsection{Kerangka Sistem}

Metode yang digunakan adalah metode Analytical Hierarchy Process (AHP) yang dilakukan untuk menentukkan peringkat dalam pemilihan supplier bahan baku. Berikut ini merupakan flowchart diagram alur penelitian :

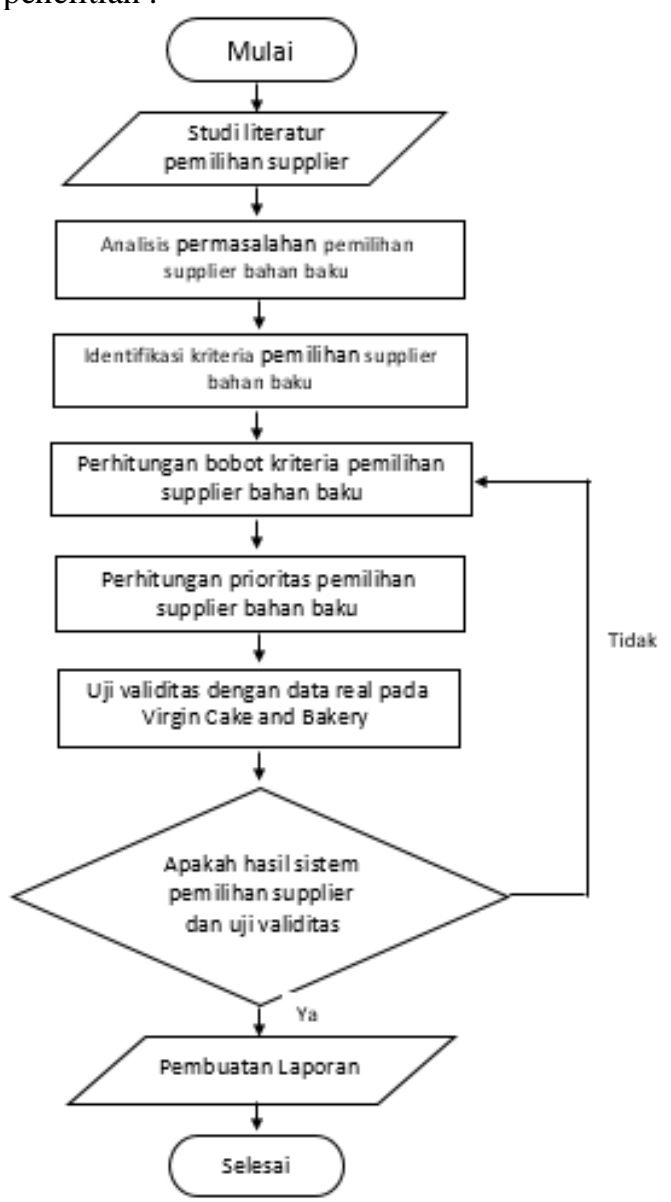

Gambar 1. Flowchart diagram alur penelitian 


\section{Metode}

\subsection{Waktu dan Tempat Penelitian}

Penelitian ini diawali dengan observasi pada tanggal 12 November 2017 untuk melakukan pengurusan ijin dan pengumpulan data yang dibutuhkan untuk perancangan dan pengembangan sistem pendukung keputusan pemilihan supplier bahan baku lalu kemudian penelitian dilakukan pada tanggal 10 Desember 2018. Tempat yang digunakan untuk penelitian ini adalah Virgin Cake and Bakery yang beralamat di Jalan Parangkusumo Raya 16-18 Tlogosari Semarang.

\subsection{Alat dan Bahan Penelitian}

Alat dan bahan yang digunakan dalam penelitian ini adalah:

1. Perangkat keras

Perangkat keras yang digunakan untuk membuat sistem pendukung keputusan yaitu komputer dengan Processor(R) Celeron (TM) Processor B820 ( 1.70 GHz, 2MB ), RAM 2 GB DDR3, Hardisk 320 GB, dan Monitor 14".

\section{Perangkat lunak}

Perangkat lunak merupakan program komputer, struktur data, dan dokumen yang berhubungan yang berfungsi untuk mempengaruhi metode logis, prosedur, dan kontrol yang dibutuhkan.

Perangkat lunak yang digunakan untuk membuat sistem pendukung keputusan yaitu Notepad $^{++}$dan Database MySQL versi , XAMPP, dan Mozilla Firefox.

3. Bahan

Bahan dalam penelitian merupakan data kriteria supplier dan data supplier bahan baku Virgin Cake and Bakery.

\subsection{Analisis Masalah}

Di Virgin Cake and Bakery sudah menerapkan pola decision making yang menggunakan metode sederhana untuk menyeleksi supplier, akan tetapi belum menggunakan sistem pendukung keputusan. Decision making merupakan suatu tindakan yang dilakukan oleh manajemen untuk mencapai tujuan organisasi dan pengambilan keputusan ini dapat didefinisikan sebagai pemilihan alternatif. Maka dari itu perlu diterapkan pemilihan supplier menggunakan sistem pendukung keputusan untuk menentukkan supplier terbaik secara kontinu.

\subsection{Teknik Pengumpulan Data}

Teknik pengumpulan yang digunakan dalam penelitian ini adalah observasi, wawancara dan studi pustaka. Observasi dan wawancara dilakukan langsung terhadap manager dari Virgin Cake and Bakery untuk mengumpulkan data-data mengenai supplier bahan baku serta angket diujikan kepada manager dan admin untuk mengetahui tingkat usability dari sistem yang dibuat. Sedangkan studi pustaka digunakan untuk memperoleh informasiinformasi yang diperlukan sebagai acuan dalam perancangan dan pembangunan sistem pendukung keputusan pemilihan supplier bahan baku.

\subsection{Teknik Analisis Data}

Dalam penelitian ini teknik analisis data menggunakan Skala Likert.

\subsection{Pembobotan Kriteria dan Subkriteria Pemilihan Supplier Bahan Baku}

Penentuan dan perhitungan bobot dari tiap-tiap kriteria dan subkriteria menggunakan metode AHP dari Saaty (1997). Berikut langkah-langkah dalam proses pembobotan kriteria dan subkriteria menggunakan metode AHP :

1. Matriks Berpasangan

Menyusun kriteria-kriteria tersebut dalam matriks berpasangan.

$a_{i j}=\frac{w_{i}}{w_{j}}, i, j=1,2,3, \ldots \ldots, n$

Dimana $n$ menyatakan jumlah kriteria yang dibandingkan, $w_{i}$ menyatakan bobot untuk kriteria ke$i$ dan $a_{i j}$ adalah perbandingan bobot kriteria $i$ dan $j$.

Hasil penyusunan kriteria-kriteria tersebut dalam matriks berpasangan ditampilkan pada Tabel 2 berikut ini.

Tabel 2. Matriks Berpasangan

\begin{tabular}{lcccrrrr}
\hline & qc & oc & up & tc & qd & gl & pc \\
\hline $\mathrm{Q}$ & 1 & 2 & 2 & 8 & 8 & 8 & 8 \\
qc & & & & & & & \\
oc & 0,5 & 1 & 1 & 4 & 4 & 4 & 4 \\
up & 0,5 & 1 & 1 & 4 & 4 & 4 & 4 \\
tc & 0,125 & 0,25 & 0,25 & 1 & 1 & 1 & 1 \\
qd & 0,125 & 0,25 & 0,25 & 1 & 1 & 1 & 1 \\
gl & 0,125 & 0,25 & 0,25 & 1 & 1 & 1 & 1 \\
pc & 0,125 & 0,25 & 0,25 & 1 & 1 & 1 & 1 \\
\hline
\end{tabular}

2. Proses Normalisasi

Menormalkan setiap kolom dengan cara membagi setiap kolom dengan cara membagi setiap nilai pada kolom ke $i$ dan baris ke $j$ dengan nilai total dari setiap kolom.

$a_{i j}=\frac{a_{i j}}{\Sigma a_{i j}}$

3. Bobot Prioritas

Menentukan bobot priritas setiap kriteria ke $i$, dengan membagi jumlah setiap nilai $a$ dengan jumlah kriteria yang dibandingkan $(n)$.

$w_{i}=\frac{\Sigma a}{n}$

4. Menentukan WSF ( Weight Single Factor )

Menetukan WSF masuk dalam kategori uji konsistensi. Dalam hal ini matriks berpasangan awal dikalikan dengan bobot prioritas kriteria.

$$
a_{i j}=\sum_{i=1}^{n} a_{i j} \times w_{i}
$$

5. Menghitung nilai CF (Consistency Factor)

Dalam menghitung nilai $\mathrm{CF}$ yaitu dengan membagi nilai WSF dengan nilai bobot prioritas. Menentukan nilai CF (Consistency Factor) dengan rumus. 


$$
C F=\frac{W S F}{B o b o t}
$$

Terdapat 7 Consistency Factor (CF) yang bernilai 7.

6. Menghitung nilai $\lambda \max$

Mengitung nilai $\lambda \max$ atau rata-rata $\mathrm{CF}$ dengan rumus.

$\lambda_{\max }=\frac{\Sigma C F}{n}$

Hasil dari $\lambda \max$ dapat dilihat pada perhitungan dibawah ini :

$$
\lambda_{\max }=\frac{\Sigma C F}{n}=\frac{(7 \times 7)}{7}=\frac{49}{7}=7
$$

7. Menghitung CI (Consistency Index)

Menghitung CI (Consistency Index) menggunakan persamaan.

$C I=\frac{\lambda_{\max }-n}{n-1}$

Hasil dari CI dapat dilihat pada perhitungan dibawah ini :

$C I=\frac{(7-7)}{7-1}=\frac{0}{6}=(-1,48)$

8. Menghitung CR (Consistency Ratio)

Mengukur seluruh konsistensi penilaian dengan menggunakan konsistensi rasio (CR) dengan rumus:

$C R=\frac{C I}{R I}$

Hasil dari CR dapat dilihat pada perhitungan dibawah ini :

$$
C R=\frac{(-1,48)}{1,41}=(-1,04)
$$

Suatu tingkat konsistensi tertentu diperlukan dalam penentuan prioritas untuk mendapatkan nilai yang terbaik. Nilai $\mathrm{CR} \leq 0,01$ adalah nilai konsistensi. Nilai CR dari hasil berhitungan adalah $(-1,04)$. Nilai $(-1,04) \leq 0,01$ sudah merupakan hasil yang konsisten. 9. Penentuan nilai bobot prioritas

Penentuan nilai bobot prioritas diperoleh dari penjumlahan nilai bobot perbandingan antara kriteria dikalikan dengan nilai bobot perbandingan alternatif dengan kriteria.

Bobot prioritas $=\sum$ (bobot perbandingan antar kriteria $\times$ bobot perbandingan alternatif dengan kriteria)

\subsection{Validitas Data}

Hasil akhir perangkingan dari sistem pendukung keputusan pemilihan supplier bahan baku di Virgin Cake and Bakery yang menggunakan metode AHP telah divalidasi dengan data di lapangan peneliti paparkan pada Tabel 3 dan Tabel 4 berikut ini.

Tabel 3. Hasil Perangkingan Sistem

\begin{tabular}{llll}
\hline No & Nama & Hasil Akhir & Ranking \\
\hline 1 & Supplier 1 & 0,3687 & 1 \\
2 & Supplier 4 & 0,2478 & 2 \\
3 & Supplier 2 & 0,1940 & 3 \\
4 & Supplier 3 & 0,1895 & 4 \\
\hline
\end{tabular}

Tabel 4. Hasil Perangkingan Virgin Cake and Bakery

\begin{tabular}{llll}
\hline No & Nama & Hasil Akhir & Ranking \\
\hline 1 & Supplier 1 & 260 & 1 \\
2 & Supplier 4 & 240 & 2 \\
3 & Supplier 2 & 225 & 3 \\
4 & Supplier 3 & 150 & 4 \\
\hline \multicolumn{5}{c}{ Berdasarkan tabel di atas, dapat disimpulkan }
\end{tabular}
bahwa hasil perangkingan dari sistem pengambilan keputusan pemilihan supplier yang peneliti kembangkan sesuai dengan data yang ada di Virgin Cake and Bakery. Hal ini menunjukkan bahwa pengembangan sistem pengambilan keputusan pemilihan supplier ini telah menghasilkan sistem yang cerdas dan dapat digunakan secara kontinu.

\section{Hasil dan Pembahasan}

\subsection{Proses dan Analisis}

Proses pemilihan supplier dilakukan oleh admin yang menginput data berupa bobot kriteria dari masing-masing supplier ke dalam sistem. Selanjutnya sistem akan mengolah data tersebut untuk menentukan peringkat supplier. Data hasil perhitungan peringkat supplier yang dihasilkan oleh sistem selanjutnya diserahkan kepada manager. Berdasarkan data peringkat tersebut, supplier terbaik akan mensupplai bahan baku di virgin cake and bakery.

\subsection{Hasil Pembuatan Sistem Pendukung Keputusan}

Hasil desain interface tetap sama pada setiap level pengguna hanya saja menu setiap level pengguna berbeda. Level pengguna pada sistem ini ada dua, yaitu admin dan manager. Hasil desain interface dapat dilihat pada Gambar 2, Gambar 3 dan Gambar 4.

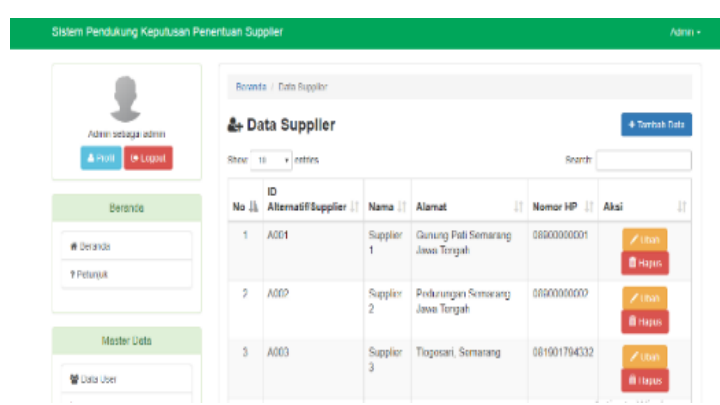

Gambar 2. Halaman data Supplier

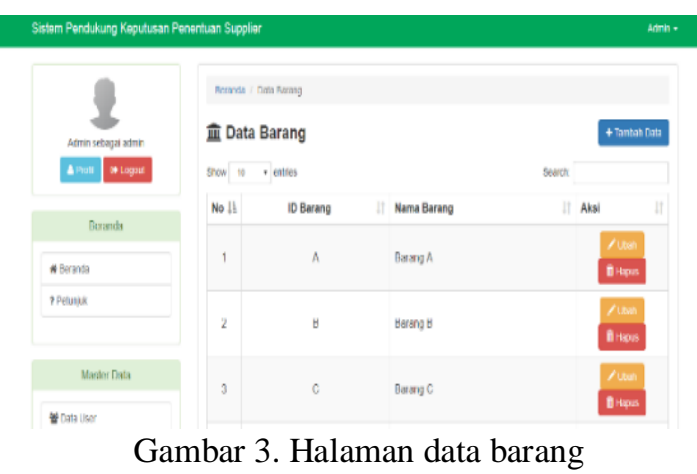




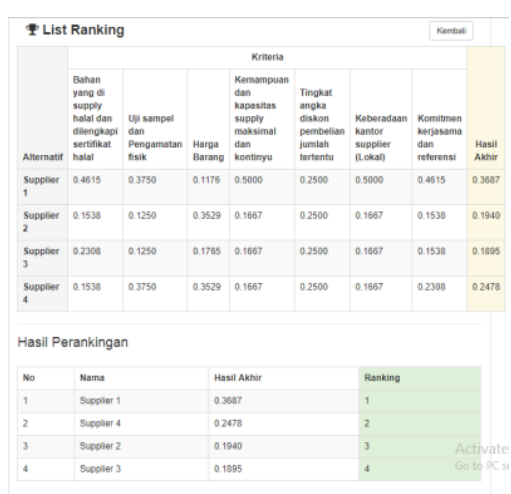

Gambar 4. Tabel perhitungan pada menu laporan ranking

\subsection{Hasil Pengolahan Data AHP}

Pengolahan data dengan pembobotan antar kriteria, alternatif, dan perangkingan yang mempengaruhi pengambilan keputusan dalam memilih supplier.

1. Pengolahan Data Tingkat Kriteria

Nilai dari setiap bobot prioritas matriks perbandingan berpasangan kriteria menunjukkan tingkat kepentingan setiap kriteria dalam pemilihan supplier Tabel 5, Tabel 6 dan Tabel 7).

Tabel 5. Kriteria dan subkriteria pemilihan supplier bahan baku

\begin{tabular}{|c|c|c|}
\hline No & Kriteria & VPI (Subkriteria) \\
\hline 1 & Quality & $\begin{array}{l}\text { Bahan yang disupply halal dan } \\
\text { dilengkapi dengan sertifikat halal }\end{array}$ \\
\hline 2 & Cost & Uji Sampel \\
\hline 3 & & Harga Barang \\
\hline 4 & & $\begin{array}{l}\text { Kemampuan kapasitas } \\
\text { maksimal dan kontinu }\end{array}$ \\
\hline 5 & Delivery & $\begin{array}{l}\text { Tingkat harga diskon pembelian } \\
\text { dalam jumlah tertentu }\end{array}$ \\
\hline 6 & & Keberadaan kantor supplier (lokal) \\
\hline 7 & Service & Komitmen kerjasama dan referensi \\
\hline
\end{tabular}

Tabel 6. Matriks berpasangan antar kriteria

\begin{tabular}{lccccccc}
\hline & Qc & Oc & Up & tc & qd & Gl & Pc \\
\hline qc & 1 & 2 & 2 & 8 & 8 & 8 & 8 \\
oc & 0,5 & 1 & 1 & 4 & 4 & 4 & 4 \\
up & 0,5 & 1 & 1 & 4 & 4 & 4 & 4 \\
tc & 0,125 & 0,25 & 0,25 & 1 & 1 & 1 & 1 \\
Qd & 0,125 & 0,25 & 0,25 & 1 & 1 & 1 & 1 \\
gl & 0,125 & 0,25 & 0,25 & 1 & 1 & 1 & 1 \\
pc & 0,125 & 0,25 & 0,25 & 1 & 1 & 1 & 1 \\
\hline
\end{tabular}

Tabel 7. Normalisasi matriks antar kriteria

\begin{tabular}{ccccccccc}
\hline & Qc & Oc & Up & Tc & qd & Gl & Pc & Bobot \\
\hline Qc & 0,4 & 0,4 & 0,4 & 0,4 & 0,4 & 0,4 & 0,4 & 0,4 \\
Oc & 0,2 & 0,2 & 0,2 & 0,2 & 0,2 & 0,2 & 0,2 & 0,2 \\
Up & 0,2 & 0,2 & 0,2 & 0,2 & 0,2 & 0,2 & 0,2 & 0,2 \\
Tc & 0,05 & 0,05 & 0,05 & 0,05 & 0,05 & 0,05 & 0,05 & 0,05 \\
qd & 0,05 & 0,05 & 0,05 & 0,05 & 0,05 & 0,05 & 0,05 & 0,05 \\
gl & 0,05 & 0,05 & 0,05 & 0,05 & 0,05 & 0,05 & 0,05 & 0,05 \\
pc & 0,05 & 0,05 & 0,05 & 0,05 & 0,05 & 0,05 & 0,05 & 0,05 \\
\hline
\end{tabular}

2. Pengolahan Data Tingkat Alternatif

Setelah menghitung bobot prioritas dari kriteria dan subkriteria maka selanjutnya adalah perhitungan bobot prioritas untuk tingkat alternatif berdasarkan subkriteria (Tabel 8 dan Tabel 9).

Tabel 8. Analisis alternatif

\begin{tabular}{|c|c|c|c|c|}
\hline Level & Subkriteria & $\begin{array}{c}\text { Perbanding } \\
\text { an } \\
\text { Alternatif }\end{array}$ & Bobot & $\begin{array}{c}\text { Konsisten } \\
\text { si }\end{array}$ \\
\hline \multirow[t]{45}{*}{$\begin{array}{l}\text { Alternat } \\
\text { if }\end{array}$} & Bahan & Supplier A & $\begin{array}{r}0,46153 \\
8\end{array}$ & 0,0 \\
\hline & disupply & Supplier B & 0,15384 & \\
\hline & halal & & 6 & \\
\hline & $(0,4)$ & Supplier C & 0,23076 & \\
\hline & & & 9 & \\
\hline & & Supplier D & 0,15384 & \\
\hline & & & 6 & \\
\hline & Uji & Supplier A & 0,375 & 0,0 \\
\hline & Sampel & Supplier B & 0,125 & \\
\hline & $(0,2)$ & Supplier C & 0,125 & \\
\hline & & Supplier D & 0,375 & \\
\hline & Harga & Supplier A & 0,11764 & 0,0 \\
\hline & Barang & & 7 & \\
\hline & $(0,2)$ & Supplier B & 0,35294 & \\
\hline & & & 1 & \\
\hline & & Supplier C & 0,17647 & \\
\hline & & & 1 & \\
\hline & & Supplier D & 0,35294 & \\
\hline & & & 1 & \\
\hline & Kemampu & Supplier A & 0,5 & 0,0 \\
\hline & an dan & Supplier B & 0,16666 & \\
\hline & kapasitas & & 7 & \\
\hline & supplai & Supplier C & 0,16666 & \\
\hline & maksimal & & 7 & \\
\hline & $(0,05)$ & Supplier D & 0,16666 & \\
\hline & & & 7 & \\
\hline & Tingkat & Supplier A & 0,25 & 0,0 \\
\hline & angka & Supplier B & 0,25 & \\
\hline & diskon & Supplier C & 0,25 & \\
\hline & $(0,05)$ & Supplier D & 0,25 & \\
\hline & Keberadaa & Supplier A & 0,5 & 0,0 \\
\hline & n kantor & Supplier B & 0,16666 & \\
\hline & supplier & & 7 & \\
\hline & $(0,05)$ & Supplier C & 0,16666 & \\
\hline & & & 7 & \\
\hline & & Supplier D & 0,16666 & \\
\hline & & & 7 & \\
\hline & Komitmen & Supplier A & 0,46153 & 0,0 \\
\hline & kerja sama & & 8 & \\
\hline & $(0,05)$ & Supplier B & 0,15384 & \\
\hline & & & 6 & \\
\hline & & Supplier C & 0,15384 & \\
\hline & & & 6 & \\
\hline & & Supplier D & 0,23076 & \\
\hline & & & 9 & \\
\hline
\end{tabular}

Tabel 9. Hasil pengolahan data tingkat alternatif

\begin{tabular}{llllllll}
\hline Alt & Qc & Oc & Up & tc & qd & Gl & pc \\
\hline Supp A & 0,46 & 0,37 & 0,11 & 0,5 & 0,25 & 0,5 & 0,46 \\
Supp B & 0,15 & 0,12 & 0,35 & 0,16 & 0,25 & 0,16 & 0,15 \\
Supp C & 0,23 & 0,12 & 0,17 & 0,16 & 0,15 & 0,16 & 0,15 \\
Supp D & 0,15 & 0,37 & 0,35 & 0,16 & 0,25 & 0,16 & 0,23 \\
\hline
\end{tabular}

3. Pengolahan Data Laporan Perangkingan

Setelah prioritas keseluruhan didapatkan, bobot masing-masing alternatif secara keseluruhan dapat dihitung dengan mengalikan bobot per alternatif 
dengan bobot kriteria, hasilnya ditunjukkan pada tabel 10 berikut ini,

Tabel 10. Hasil Perangkingan

\begin{tabular}{llc}
\hline Nama & Bobot & Peringkat \\
\hline Supplier A & 0,368722 & 1 \\
Supplier B & 0,193986 & 3 \\
Supplier C & 0,189461 & 4 \\
Supplier D & 0,247832 & 2 \\
\hline
\end{tabular}

Dari Tabel 10 diatas, menunjukkan bahwa secara keseluruhan supplier terbaik yang akan dipilih oleh perusahaan untuk dijadikan sebagai rekan kerja jangka panjang adalah supplier A karena secara keseluruhan supplier ini memiliki nilai paling tinggi dibandingkan dengan tiga supplier yang lain.

Uji pengguna dilakukan dengan mendemokan sistem kepada responden, responden kemudian memeriksa, mencoba sistem, dan menilai sistem secara keseluruhan dengan mengisi angket. Rekap hasil uji pengguna dapat dilihat pada Tabel 11 berikut ini,

Tabel 11. Rekap hasil uji pengguna

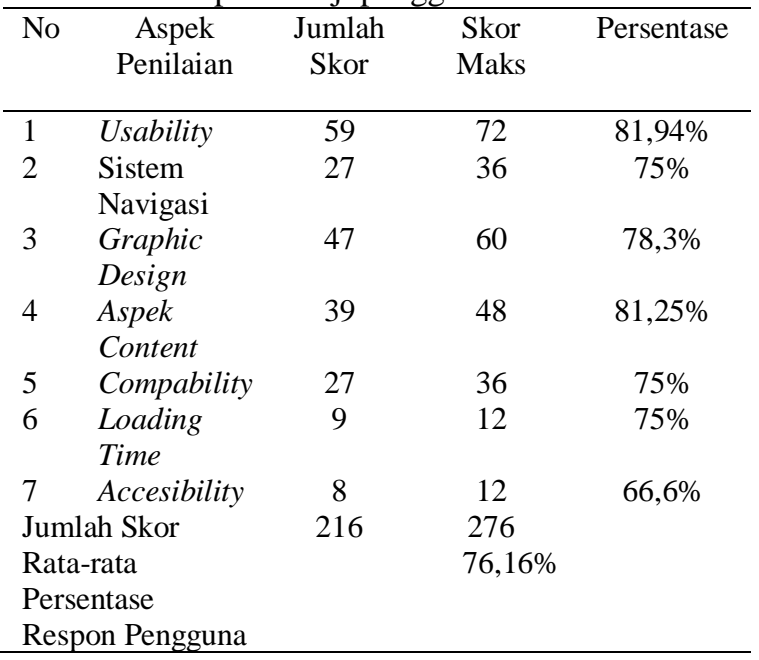

\subsection{Pembahasan}

Pembahasan dalam penelitian ini dapat dijabarkan sebagai berikut, metode AHP adalah sebuah metode yang dapat digunakan untuk menyelesaikan multicriteria decision making. Pada penelitian ini sistem pendukung keputusan pemilihan supplier bahan baku di Virgin Cake and Bakery adalah suatu sistem yang dapat membantu dan mempermudah tugas admin dan manajer dalam menentukan supplier bahan baku. Penggunaan metode AHP pada pemilihan supplier pada industri otomotif di Pakistan, proses pengolahan data untuk memperoleh bobot masingmasing kriteria menggunakan bantuan software expert choice ver 2000. Sedangkan, dalam penelitian sistem pendukung keputusan pemilihan supplier bahan baku menggunakan metode Analytichal Hierarchy Process di Virgin Cake and Bakery, proses dan hasil pengolahan data menggunakan website dan database.
Dari hasil analisis AHP diatas, kriteria yang paling berpengaruh dalam pemilihan supplier pada Virgin Cake and Bakery adalah kriteria bahan yang disupplai halal (quality) dengan bobot 0,4 . Kriteria selanjutnya yang berpengaruh adalah uji sampel (operating controls) dan harga barang (unit price) dengan bobot 0,2 . Kriteria selanjutnya yaitu kemampuan dan kapasitas supplai (technical capability), angka diskon (quantity discount), keberadaan kantor supplier (geographical location), dan komitmen kerja sama (procedural compliance) dengan bobot 0,05.

Dengan tingginya nilai bobot quality dalam pemilihan supplier menunjukkan bahwa Virgin Cake and Bakery mengutamakan kualitas yang tinggi untuk bahan baku yang akan digunakan. Hal ini dikarenakan bahan baku yang berkualitas baik akan berpengaruh baik pada kualitas produk jadinya. Sebaliknya, penggunaan bahan baku yang kurang berkualitas akan menurunkan kualitas produk jadinya.

Secara keseluruhan, berdasarkan subkriteria dalam pemilihan supplier, supplier A dinilai sebagai supplier terbaik dengan nilai bobot 0,368 . Selanjutnya adalah supplier D dengan nilai bobot 0,247 dan supplier B dengan nilai bobot 0,193 , serta supplier $\mathrm{C}$ dengan nilai bobot 0,189 . Hasil ini menunjukkan bahwa secara keseluruhan supplier terbaik yang akan dipilih oleh perusahaan untuk dijadikan sebagai rekan kerja jangka panjang adalah supplier A karena secara keseluruhan supplier ini memliki nilai paling tinggi dibandingkan dengan tiga supplier yang lain.

Tanggapan dari pengguna terhadap sistem pendukung keputusan pemilihan supplier bahan baku didapat dari kuesioner terhadap 3 responden yang terdapat pada lampiran. Peneliti menggunakan kuesioner dengan menggunakan range penskoran dengan persentase perskoran seperti yang dijelaskan pada tabel 10. Kuesioner diberikan kepada responden di Virgin Cake and Bakery yang terdiri dari 1 manajer dan 2 admin. Analisis pada pembahasan menggunakan teknik analisis deskriptif kualitatif yang hasilnya berupa predikat yang diteliti sesuai dengan kondisinya. Dari hasil tanggapan pengguna disimpulkan bahwa secara umum sistem pendukung keputusan pemilihan supplier bahan baku sudah memenuhi kriteria yang "baik" dengan persentase $76,16 \%$.

Dari hasil penelitian dan pembahasan diatas menunjukkan bukti bahwa pekerjaan ini telah mendapatkan suatu sistem pendukung keputusan baru untuk pemilihan supplier bahan baku industri makanan berdasar metode yang handal yaitu AHP pada studi kasus Virgin Cake and Bakery Semarang.

\section{Kesimpulan}

Pada penelitian ini telah dikembangkan suatu sistem pendukung keputusan baru untuk industri makanan menggunakan Analytical Hierarchy Process (AHP). Sistem ini telah diuji dengan Virgin Cake and 
Bakery Semarang. Kriteria yang paling berpengaruh dalam pemilihan supplier pada Virgin Cake and Bakery adalah kriteria bahan yang disupplai halal (quality) dengan bobot 0,4 ; uji sampel (operating controls) dan harga barang (unit price) dengan bobot 0,2 ; kemampuan dan kapasitas supplai (technical capability), angka diskon (quantity discount), keberadaan kantor supplier (geographical location), dan komitmen kerja sama (procedural compliance) dengan bobot 0,05 . Secara keseluruhan, berdasarkan subkriteria dalam pemilihan supplier, supplier A dinilai sebagai supplier terbaik dengan nilai bobot 0,368 . Selanjutnya adalaha supplier $\mathrm{D}$ dengan nilai bobot 0,247 dan supplier B dengan nilai bobot 0,193, serta supplier $\mathrm{C}$ dengan nilai bobot 0,189 . Hasil ini menunjukkan bahwa secara keseluruhan supplier terbaik yang akan dipilih oleh perusahaan untuk dijadikan sebagai rekan kerja jangka panjang adalah supplier A karena secara keseluruhan supplier ini memiliki nilai paling tinggi dibandingkan dengan tiga supplier yang lain.

\section{Ucapan Terima Kasih}

Penulis mengucapkan terima kasih terhadap UEESRG, Jurusan Teknik Elektro dan pihak Virgin Cake and Bakery yang telah memberikan support dari data serta sarana dan prasarana.

\section{Daftar Pustaka}

Ilham, A.S., 2006. Produktivitas \& Efisiensi dengan Supply Chain Management. Jakarta: PPM

Akarte, M., Surendra, N.V., Ravi, B. and Rangaraj, N., 2001. Web based casting supplier evaluation using analytical hierarchy process. The Journal of the Operational Research Society. Vol. 52, No. 5, pp. 511-522.

Chan, F., 2003. Performance measurement in a supply chain. The International Journal of Advanced Manufacturing Technology. Vol 21, pp 534-548.

Chan, A., Kwok, W.Y. and Vincent G.D., 2004. Using AHP for determining priority in a safety management system. Industrial management and data system Vol 104.
Beil, D.R., 2010. Supplier Selection, preented at the Wiley Encyclopedia of Operations Research, vol.202, pp. 16-24, 2010

Dweiri, Fikri dan Sameer, K., 2016. Designing an integrated AHP based decision support system For Supplier Selection In Automotive Industry. Expert Systems With Applications. pp 273-283

Gencer, C. dan Didem, G., 2007. analytic network process in supplier selection: a case study in a electronic firm. Applied Mathematical Modelling. pp 2475-2486

Liu, Fuh-Hwa F. and Hui, L.H., 2005. The voting analytic hierarchy process method for selecting Supplier. International Journal of Production Economics. pp 308-317

Hasan, M.A., 2008. Supplier selection in a agile manufacturing environment using data envelopment analysis and analytical network process, International Journal of Logistics Systems and Management, vol. 4, pp. 523-550, 2008.

Muralidharan, C., Anantharaman, N. and Deshmukh, S.G., 2002. A multi-criteria group decisionmaking model for supplier rating. The Journal of Supply Chain Management. Pp. 22-35.

Nugraha, D.W. dan Wirdayanti, 2013. Sistem pendukung keputusan pemilihan supplier menggunakan metode Analytichal Hierarchy Process (AHP). Jurnal Ilmiah Foristek. Vol. 3, No 2

Rahmayanti, R., 2010. Analisis pemilihan supplier menggunakan metode Analytichal Hierarchy Process (AHP). Skripsi. Universitas Sebelas Maret Surakarta

Sulistiana, W. dan Evi, Y., 2012. Analisis pemilihan supplier bahan baku dengan menggunakan metode Fuzzy Analytical Hierarchy Process (FAHP). Jurnal Teknik Industri. Vol. 12, No 20

Xia, W., and Zhiming, Wu., 2007. Supplier selection with multiple criteria in volume discount environments. The International Journal of Management Science. pp 494-504 